\title{
HTLV-1 infection interferes with immune responses to Mycobacterium tuberculosis antigens
}

\author{
Natália B Carvalho ${ }^{1 *}$, Maria de Lourdes Bastos ${ }^{1}$, Yuri Neves ${ }^{1}$, Anselmo Souza', Eduardo Martins Netto ${ }^{2,3}$, \\ Silvane Santos ${ }^{1,4}$, Edgar M Carvalho ${ }^{1}$ \\ From 17th International Conference on Human Retroviruses: HTLV and Related Viruses \\ Trois Ilets, Martinique. 18-21 June 2015
}

Tuberculosis (TB) is still a major health problem. IFN- $\gamma$ and TNF are critical cytokines in the control of Mycobacterium tuberculosis (Mtb) infection. It has already been demonstrated that human $\mathrm{T}$ cell lymphotropic virus type 1 (HTLV-1) infection leads to a spontaneous IFN- $\gamma$ and TNF production, however HTLV-1 infected subjects possess a 2-4 fold increased risk of developing tuberculosis. Nevertheless, the immune mechanisms involved in this phenomenon are still unclear. The aim of this study was to evaluate immunological features of the association between HTLV-1/Mtb in order to better understand the events leading to higher susceptibility to TB observed in HTLV-1 infected subjects. This was a cross-sectional study evaluating four groups: healthy control (HC group), HTLV-1 infected subjects without TB (HTLV-1 group) or with TB (HTLV-1 + TB group), and individuals with only TB (TB group). TNF, IL- $1 \beta$, and IL-17 levels were measured in supernatants of nonstimulated or PPD stimulated peripheral blood mononuclear cells (PBMCs) by ELISA. PBMCs from HTLV-1 infected individuals had a decrease $(\mathrm{p}<0.05)$ in TNF production following PPD stimulation (median $114.5 \mathrm{pg} / \mathrm{ml}$, IQ range 47-189 $\mathrm{pg} / \mathrm{ml}$ ) compared to non-stimulated cells $(202 \mathrm{pg} / \mathrm{ml}$, IQ range $100-250 \mathrm{pg} / \mathrm{ml})$. When we normalized the data to non-stimulated cells, IL-1 $\beta$ production following PPD stimulation by individuals in the HTLV-1 + TB group (3 pg/ml, IQ range $0-43 \mathrm{pg} / \mathrm{ml})$ was lower $(\mathrm{p}<0.05)$ than in patients with TB $(87 \mathrm{pg} / \mathrm{ml}$, IQ range $14-151 \mathrm{pg} / \mathrm{ml})$. Similarly, HTLV-1/Mtb coinfected individuals had lower $(\mathrm{p}<0.05)$ production of IL-17 (9 pg/ml, IQ range 0-41 pg/ml) when compared

\footnotetext{
* Correspondence: carvalhonb@gmail.com

${ }^{1}$ Serviço de Imunologia do Complexo Hospitalar Universitário Professor Edgard Santos (Com-HUPES), Universidade Federal da Bahia (UFBA), Salvador-BA, Brasil

Full list of author information is available at the end of the article
}

to TB patients $(43 \mathrm{pg} / \mathrm{ml}$, IQ range $13-150 \mathrm{pg} / \mathrm{ml})$. Impairment in TNF, IL-1 $\beta$, and IL-17 production upon stimulation with mycobacterial antigens may contribute to the higher susceptibility to Mtb infection observed in HTLV-1 infected subjects. Financial support: CNPq, CAPES.

\begin{abstract}
Authors' details
'Serviço de Imunologia do Complexo Hospitalar Universitário Professor Edgard Santos (Com-HUPES), Universidade Federal da Bahia (UFBA), Salvador-BA, Brasil. ²Laboratório de Pesquisa em Infectologia, Com-HUPES, UFBA, Salvador-BA, Brasil. ${ }^{3}$ Instituto Brasileiro para a Investigação da Tuberculose/FJS, Salvador-BA, Brasil. ${ }^{4}$ Departamento de Ciências Biológicas, Universidade Estadual de Feira de Santana, Feira de Santana-BA, Brasil.
\end{abstract}

Published: 28 August 2015

doi:10.1186/1742-4690-12-S1-024

Cite this article as: Carvalho et al:: HTLV-1 infection interferes with immune responses to Mycobacterium tuberculosis antigens. Retrovirology 2015 12(Suppl 1):O24.

Submit your next manuscript to BioMed Central and take full advantage of:

- Convenient online submission

- Thorough peer review

- No space constraints or color figure charges

- Immediate publication on acceptance

- Inclusion in PubMed, CAS, Scopus and Google Scholar

- Research which is freely available for redistribution

Submit your manuscript at www.biomedcentral.com/submit
() Biomed Central 